\title{
温暖地における住宅用全熱交換換気ユニットの導入効果 戸建住宅に扔ける全熱交換換気ユニットの導入効果に関する研究 その 1 EFFECTIVENESS OF RESIDENTIAL TOTAL HEAT EXCHANGER UNITS IN MILD CLIMATE REGIONS
}

A study on effectiveness of total heat exchanger units in detached houses Part 1

\section{鳥海吉 弘*, 倉㴊 隆**, 奥山博 康 ${ }^{* *}$, 七岡 寛 ${ }^{* * * *}$ Yoshihiro TORIUMI, Takashi KURABUCHI, Hiroyasu OKUYAMA and Hiroshi NANAOKA}

\begin{abstract}
Total heat exchangers are useful in reducing thermal load of heating and cooling systems with high electric power consumption because they decreases fresh air load, and consequently are the subject of much expectation - especially with regards to their energy saving effect in regions with under cold climatic conditions. In the present study, an evaluation was on the thermal comfort and energy saving effect when total heat exchangers were adopted for detached houses in a mild climate region. The results of the study suggest that the heating load can be reduced by about $10 \%$ and heat recovery may have a reverse effect in intermediate seasons, and also have a small effect on the cooling load, but the cooling load can be reduced by about $20 \%$ by utilizing natural ventilation.
\end{abstract}

Keywords : Simulation, Total heat exchanger, Mechanical ventilation, Thermal load, Energy conservation, Mild climate region シミュレーション, 全熱交換器, 機械換気, 熱負荷, 省エネルギー, 温暖地

\section{1.はじめに}

2003 年 7 月の建築基準法の改正により，原則として住宅への機 械換気設備の設置が義務付けられ，省エネルギーの観点から寒冷地 では全熱交換器の導入が増えると予想される。日本の住宅用エネル ギーのうち，冷暖房設備による消費が 3 割程度を占める ${ }^{2)}$ ことから も，その有効性を把握することが重要であるといえる。全熱交換器 は，室内空気污染対策の一つであるが，冬季の外気の直接流入によ る不快感及び水分排出による過乾燥の防止など健康 ・快適性に加え て，換気による熱損失を防止することで省エネルギー化が図れるな どの利点がある ${ }^{3)}$ 。しかしながら, 使用する地域や, 全熱交換器を 利用するデメリット，例えば全熱交換換気ユニットの構造上起こり うる有効換気量率の問題や, 全熱交換器の熱交換素子による換気動 力（搬送動力）の増加などが問題になってくる。この問題に関して, 系統的に研究した例はほとんどない。

熱交換効率やエンタルピー交換効率から全熱交換器の導入効果が 試算されるが，外界気象条件，建物の断熱・気密性能，空の開閉状 況, 冷暖房設備の発停・内部発熱スケジュールなど, 全熱交換器が エネルギー消費に及ぼす影響を総合的に分析する必要がある。中村
$ら^{4)}$ は，断熱性・気密性の高い実験住宅を蒸暑地（鹿児島）に設置 し, 梅雨期の全熱交換器の熱交換状況測定を行い，換気ダクト内の 給気温度が外気温度や室温よりも高い值で供給されていることや, 全熱交換器による換気だけでは室内が高湿となっていることから， 従来の全熱交換器を連続運転するのは問題点が多いことを指摘して いる。しかしながら，地域が鹿児島に限定されており，全熱交換器 のない状況との比較や, 調理・家電機器による発熱や発湿を考慮し ていない。一方，持田 ${ }^{5), 6), 7)}$ は，集合住宅に太陽熱や外気等の自 然エネルギーを効率的に導くシステムを提案し，その中でバイパス 機能を備えた全熱交換器を組み込み，シミュレーションによる省エ ネルギー効果と実測によるシステムの運転状況を評価している。こ こでも地域が限定されており，シミュレーションによる検討では， 空気式集放熱パネルをシステムに組み込んだ自然冷暖房換気システ ムとして評価しているため, 全熱交換器単体としての省エネルギー 効果が評価されておらず，住戸も単室として全館冷暖房している。 また，実測による検討では，居住状態での計測になっていない。

本研究では，実測から得られた特性值を使用して全熱交換換気工 ニットのモデルを構築し，在室・内部発熱や空開閉スケジュールを 含めた建物・全体モデルに組み込み, 地域性を含めた全熱交換器の

\footnotetext{
本論文は，既発表論文 ${ }^{1)} も と に$ 加筆・修正したものである。

$*$ 職業能力開発総合大学校 講師 $\cdot$ 博士 $($ 工学 $)$

** 東京理科大学工学部 教授・博士 (工学)

$* * *$ 清水建設(株)技術研究所上席研究員.工博

**** 大和八ウス工業(株)総合技術研究所
}

Lect., Polytechnic University, Dr. Eng.

Prof., Faculty of Engineering, Tokyo University of Science, Dr. Eng.

Chief Research Engineer, Institute of Technology, Shimizu Corporation, Dr. Eng.

Central Research Laboratory, Daiwa House Industry Co., Ltd. 
導入効果を, 年間を通じて様々な角度から評価することを目的とし ている。実測でこの効果を調查し結論を導く事は困難であるが，シ ミュレーションによれば可能である。シミュレーションプログラム に $\mathrm{NETS}^{8)}$ を使用し, 全熱交換器の導入効果を検証する。本報（そ の 1) では, 計算モデルの概要と温暖地（東京）における全熱交換 器の導入効果と利用法について報告する。

\section{2. 全熱交換換気ユニットのモデル}

従来，熱交換器の計算モデルには，熱交換効率を定数的に仮定す る算術計算的なモデル ${ }^{9}$ や, 対数平均温度差を用いた半解析的なモ デル ${ }^{10)}$ などがあるが，いずれも入口空気の状態を与えて出口空気の 状態を算出するものである。また，全熱交換器と送風機を一体化し て用いられている全熱交換換気ユニットでは，排気系(RA-EA)空気 が給気系(OA-SA)空気に混入することや，ユニットからの吸引・吹 出しも考えられる。この現象も考慮するには従来の計算モデルでは 不十分である。そこで, 関連する既往研究 ${ }^{11}$ から, 熱・水蒸気・換 気を連成した回路網モデルに改良した。

\section{1 換気回路網モデル}

全熱交換換気ユニット本体には各部に微少隙間が存在し，ここか らの漏気は，熱移動や水蒸気移動の一因となり，熱交換効率及びエ ンタルピー交換効率にも大きな影響を及ぼすものと考えられる。こ のため, まず換気回路網モデルを構築し, 各部風量・漏気量等を再 現した上で, 熱回路網及び水蒸気回路網モデルを構築する。対象ユ ニットは，ユニット内部が負圧となる直交流型全熱交換器とし，換 気回路網については図 1 の様なモデル構造を仮定した。ユニット内 部をゾーンに分割し，その間の各流路を式(1)のようにモデル化する 8).

$$
\Delta P=\zeta \frac{\rho}{2}\left(\frac{Q}{A}\right)^{\eta}
$$

ここに, $\Delta P$ : 差圧 $[\mathrm{Pa}], \zeta$ : 圧力損失係数又は局部抵抗係数 $[-]$, $\rho:$ 空気密度 $\left[\mathrm{kg} / \mathrm{m}^{3}\right], Q:$ 風量 $\left[\mathrm{m}^{3} / \mathrm{s}\right], \mathrm{A}:$ 流路断面積 $\left[\mathrm{m}^{2}\right], \eta$ : 圧力 損失指数 $[-]$, である。

各流路の隙間特性については, 既往研究 ${ }^{11)}$ から, 熱交換素子部の 圧力損失係数を表 1 の様に与える。送風機特性（PQ 特性）を図 2 に示す。建物モデルへ本ユニットをそのまま適用するには風量が大 き過ぎるため, 必要換気量まで減らす必要があった。図 2 で「変更」 と示すように，ユニットの圧力損失に，設計時の想定全圧を加えた 状態で設計風量が得られるように，給気( $\mathrm{SA}$ ・・排気(EA)ファン共に $\mathrm{PQ}$ 特性を極座標的に相似になるよう修正している注1)。なお，シミ ュレーションの入力上の都合から，変更後の $\mathrm{PQ}$ 特性は，全圧基準 としている。

\section{2 熱・水蒸気回路網モデル}

換気回路網モデル構築後，熱と水蒸気に関する特性をカタログ性 能（技術資料，熱・エンタルピー交換効率一風量の特性曲線）から モデル化した。移流を除く熱・水蒸気回路網モデルを図 3 に示す。 熱交換素子については，まず対数平均温度（湿度）差の考え方によ り貫流率 $\times$ 面積を求め, 熱・水蒸気の交換過程を滑らかに模擬するた めに 5 分割している。さらに，ダクト系の圧力損失を加えた状態で カタログ性能を再現する様に，熱コンダクタンスと湿気コンダクタ ンスを調整した。熱と水蒸気に関する特性を表 2 に示す注2)。

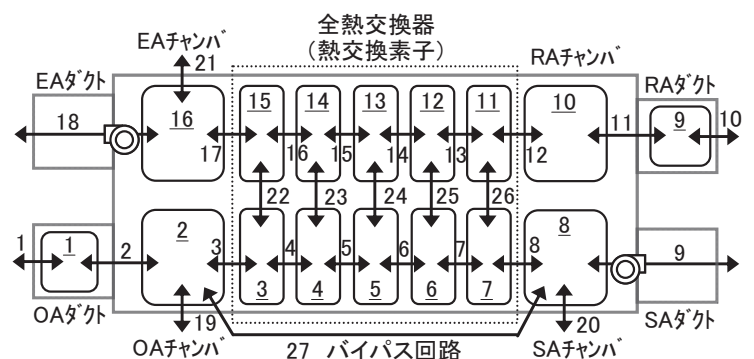

図中の矢印・数值は，流路・番号を表し，アンダーライン付き数字 はゾーン番号を示す。 $\mathrm{OA}$ : 外気， $\mathrm{SA}$ : 給気， RA : 還気， EA : 排気

図 1 全熱交換換気ユニットの換気回路網モデル

表 1 全熱交換換気ユニット各部位の隙間特性

\begin{tabular}{|c|c|c|c|c|c|}
\hline 流路No. & 系統(種別) & 部 & ゾーンNo. & $\zeta$ & $\eta$ \\
\hline $1^{\dagger 1}$ & OA-SA & 外気一OAダクト & 外気 -1 & - & - \\
\hline 2 & OA-SA & OAダクトーチャンバ & $1-2$ & 31601 & 2.000 \\
\hline $3 \sim 8$ & $\begin{array}{c}\text { OA-SA } \\
\text { (抵抗) }\end{array}$ & 熱交換素子 & $\begin{array}{l}2-3,3-4 \\
4-5,5-6 \\
6-7,7-8\end{array}$ & 491 & 1.542 \\
\hline $9^{\dagger 1}$ & OA-SA & SAチャンバー室内 & 8-各室 & - & - \\
\hline $10^{\dagger 1}$ & RA-EA & 室内ーRAダクト & 1階ホール-9 & - & - \\
\hline 11 & RA-EA & RAダクトーチャンバ & $9-10$ & 5628 & 2.000 \\
\hline $12 \sim 17$ & $\begin{array}{c}\text { RA-EA } \\
\text { (抵抗) }\end{array}$ & 熱交換素子 & $\begin{array}{l}10-11,11-12 \\
12-13,13-14 \\
14-15,15-16\end{array}$ & 387 & 1.413 \\
\hline $18^{\dagger 1}$ & RA-EA & EAチャンバー外気 & 16-外気 & - & - \\
\hline 19 & （漏気） & OAチャンバ内外 & 1階ホールー2 & 684567 & 1.030 \\
\hline 20 & （漏気） & $\mathrm{SA}$ チャンバ内外 & 1階ホール-8 & 163899 & 1.169 \\
\hline 21 & (漏気) & EAチャンバ内外 & 1階ホール-16 & 85103 & 1.000 \\
\hline $22 \sim 26$ & （漏気） & 熱交換素子 & $\begin{array}{c}3-15,4-14 \\
5-13,6-12 \\
7-11\end{array}$ & 453311 & 1.086 \\
\hline $27^{\dagger 2}$ & OA-SA & バイパス回路 & $2-8$ & 14605 & 2.000 \\
\hline
\end{tabular}

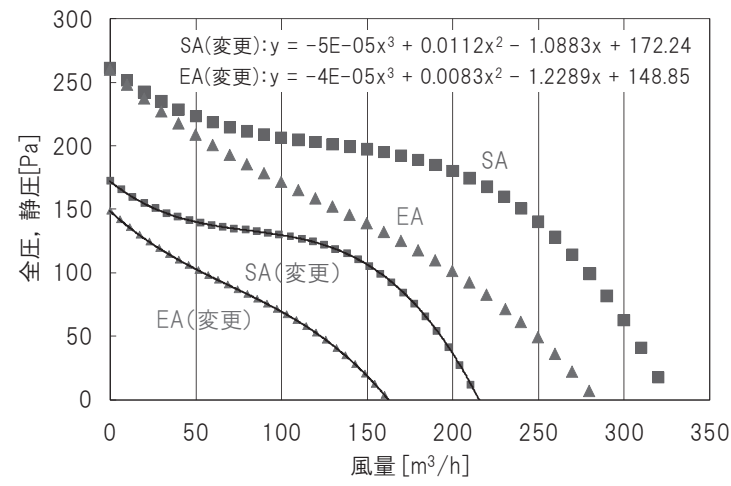

図 2 送風機の $\mathrm{PQ}$ 特性（「変更」は全圧基準）

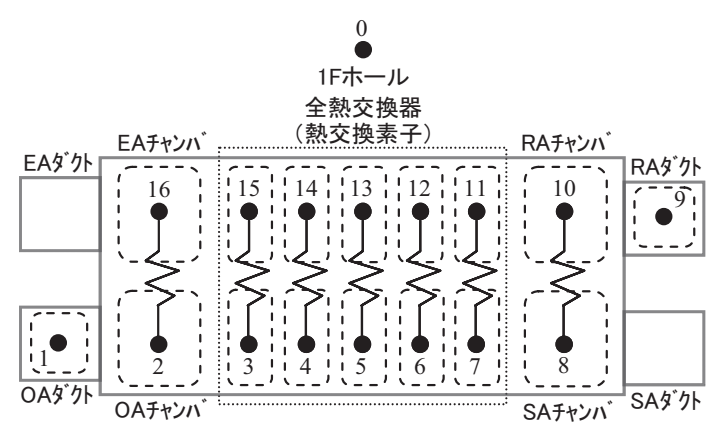

図 3 全熱交換換気ユニットの熱・水蒸気回路網モデル 
全熱交換換気ユニットの設置は 1 階ホールに想定している注3)。ま た, 全熱交換換気ユニットの構造上, ケーシング漏気はチャンバ漏 気として取り扱う。

\section{3 モデルの検証}

このモデルで JIS B $8628^{3)}$ の熱交換効率測定方法に従い計算し, カタログ值と比較したものが表 3 であり, 概齐カタログ值を再現で きているが，冷房時のエンタルピー交換効率はカタログ值より $16 \%$ 高い值となった。エンタルピー交換効率は, 熱交換素子の顕熱と潜 熱の交換効率の違いや測定時の空気条件に依存するが, 計算值はカ タログ值のような暖房時と冷房時のエンタルピー交換効率に大きな 差が見られない。冷房時の潜熱交換を過大評価することになるが, 潜熱交換の絶対量が小さいため, 水蒸気移動の定性的傾向に変化を 及ぼさないと考え, 熱・湿気特性に変更を加えなかった。このモデ ルについて, 本ユニットにつながるダクト系の圧力損失を変化させ, 有効換気量率 (排気系から給気系への混入率注 4) $)$ の変化を計算した 結果を表 4 に示す。なお, ダク卜抵抗の変化は, 定格状態から変化 させ，当該ダクト以外のダクトの圧力損失はなりゆきとした。有効 換気量率は, 給気 $(\mathrm{SA})$ 系統の圧力損失減少に対しては微減, 還気 (RA)系統の圧力損失増加に対しては増加, 排気 (EA)系統の圧力損失 増加に対しては微増（表 4 では変化なし）, 外気 $(\mathrm{OA})$ 系統の圧力損 失増加に対しては大きく減少しており, 表 4 は既往研究 ${ }^{11)}$ の結果を 反映している。

\section{3. 建物・全体モデル}

対象とした住宅は, 図 4 に示寸都市型の戸建住宅とした。延床面 積は $122.1 \mathrm{~m}^{2}$, 建物全体の気積(小屋裏・床下空間を含む) は $363.1 \mathrm{~m}^{3}$ となっている。

\section{1 気象データ・風圧係数}

気象データは，拡張 AMeDAS 標準年気象データ ${ }^{12)}$ を使用する。 風速は, べき指数 $\alpha=0.25$ で風圧力計算用基準高さ $5.8 \mathrm{~m}$ の值に高度 補正した。風圧係数は住宅の密集度により変化すると思われるが, グロス建蔽率が $30 \%$ 超えると壁面風圧係数の差が小さい ${ }^{13)}$ こと から, 模型の周辺環境を市街地として想定した風洞実験による実測 值(日本大学生産工学部建築工学科 丸田研究室) を使用する。なお, ダクトや換気口などの屋外端末にも当該壁面の風圧係数を割り当て ている。

\section{2 断熱性能・気密性能}

地域の区分に応じた「熱貫流率の基準值」(鉄筋コンクリート造等 以外のその他の住宅） ${ }^{97}$ に従い，必要に応じて断熱材の厚さを調整 した。外皮 (断熱部位) となるのは, 外壁面, 天井（上部小屋裏）, 床（下部床下）とした。使用した室内側及び外気側表面の熱伝達抵 抗を表 5 に示す。

気密性能に関して, 空・玄関ドアの開口部は, I ・ II 地域が「A-4 等級」, それ以外の地域が「A-3 等級」(JIS A 4702, JIS A 4706) 相当とした。隙間に関しては, $1 / \mathrm{n}=0.65$ ( $\mathrm{n}$ : 隙間特性係数), 建具 の周囲に沿って細長い隙間が存在するものとし, 竪隙間を上下 2 分 割，横隙間を建具の上下（開口部によっては上中下）に設定した。 内部扉に関しては, アンダーカット（相当隙間面積 $\alpha \mathrm{A}=125 \mathrm{~cm}^{2}$ ）を 想定, $1 / \mathrm{n}=0.5$ (単純開口) とした。なお, ドア・内部扉以外の内壁 等一般部や $1 \cdot 2$ 階間の床は完全気密とした。建物全体の気密性能
表 2 全熱交換換気ユニット各部位の熱・湿気特性

\begin{tabular}{|c|c|c|c|}
\hline 節点No. & 部位 & $\begin{array}{c}\text { 熱コンダクタンス } \\
\text { [W/K] } \\
\end{array}$ & $\begin{array}{c}\text { 湿気コンダクタンス } \\
{[\mathrm{kg} / \mathrm{s}(\mathrm{kg} / \mathrm{kg})]} \\
\end{array}$ \\
\hline $2-16$ & OA-EAチャンバ & 0.78875 & 0 \\
\hline $3-15$ & \multirow{5}{*}{ 熱交換素子 } & \multirow{5}{*}{34.8837} & \multirow{5}{*}{0.025} \\
\hline $4-14$ & & & \\
\hline 5-13 & & & \\
\hline $6-12$ & & & \\
\hline $7-11$ & & & \\
\hline $8-10$ & SA-RAチャンバ & 0.78875 & 0 \\
\hline $0-2$ & 1階ホールーチャンバ & 1.04 & - \\
\hline $0-3$ & \multirow{5}{*}{ 1階ホール－熱交換素子 } & \multirow{5}{*}{0} & \multirow{5}{*}{-} \\
\hline $0-4$ & & & \\
\hline $0-5$ & & & \\
\hline $0-6$ & & & \\
\hline $0-7$ & & & \\
\hline $0-8$ & 1階ホールーチャンバ & 1.04 & - \\
\hline $0-10$ & 1階ホールーチャンバ & 1.04 & - \\
\hline $0-11$ & \multirow{5}{*}{ 1階ホール－熱交換素子 } & \multirow{5}{*}{0} & \multirow{5}{*}{-} \\
\hline $0-12$ & & & \\
\hline $0-13$ & & & \\
\hline $0-14$ & & & \\
\hline $0-15$ & & & \\
\hline $0-16$ & 1階ホールーチャンバ & 1.04 & - \\
\hline
\end{tabular}

表 3 カタログ值と計算值の比較

\begin{tabular}{c|c|c|c|c|c}
\hline \multirow{2}{*}{ 項 目 } & 熱交換効率 & \multicolumn{2}{|c|}{ エンタルピー交換効率[\%] } & SA風量 & EA風量 \\
\cline { 3 - 6 } & {$[\%]$} & 冷房 & 暖房 & {$\left[\mathrm{m}^{3} / \mathrm{h}\right]$} & {$\left[\mathrm{m}^{3} / \mathrm{h}\right]$} \\
\hline カタログ值 & 67 & 48 & 66 & 135 & 不明 \\
\hline 計 算 值 & 68 & 64 & 67 & 135 & 122 \\
\hline
\end{tabular}

表 4 ダクトの圧力損失変化による有効換気量率の変化

\begin{tabular}{c|c|c|c|c|c}
\hline \multirow{2}{*}{ 項 $\quad$ 目 } & \multicolumn{4}{|c|}{ ダクケの圧力損失[Pa] } & $\begin{array}{c}\text { 有效換気量率[\%] } \\
\text { (給気系の混入率) }\end{array}$ \\
\hline 定 格 & 110.2 & 29.7 & 19.9 & 20.0 & 94.5 \\
\hline $\mathrm{SA} \times 0.5$ & 55.1 & 29.7 & 19.9 & 20.0 & 94.4 \\
\hline $\mathrm{RA} \times 2$ & 110.3 & 59.8 & 19.9 & 21.2 & 97.2 \\
\hline $\mathrm{EA} \times 2$ & 110.2 & 30.6 & 39.8 & 20.0 & 94.5 \\
\hline $\mathrm{OA} \times 2$ & 110.2 & 30.7 & 19.9 & 39.8 & 91.2 \\
\hline $\begin{array}{l}\mathrm{EA} \times 2 \\
\mathrm{OA} \times 2\end{array}$ & 110.1 & 31.7 & 39.8 & 39.8 & 91.2 \\
\hline
\end{tabular}
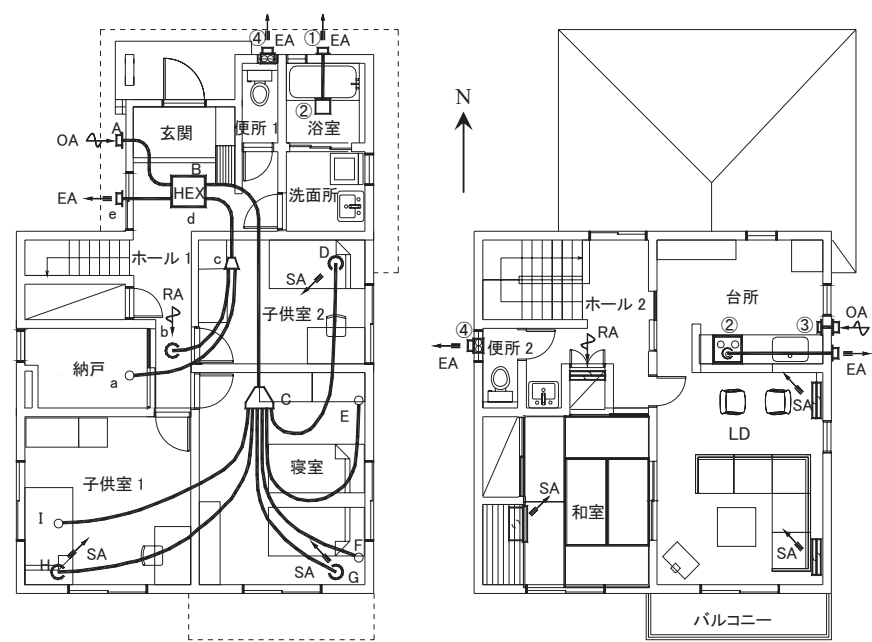

(1)排気用パイプファン (2)浴室天井扇 HEX : 全熱交換換気ユニット

$\rightarrow$ : 天井面の吹出し・吸込み口 $\equiv$ : 吹出し

(3)レンジフードファン（4)換気口

一: :ダクト立ち上がり部

曰: 床面の吹出し・吸込み口

$\checkmark$ : 吸込み

図4 平面図兼換気設備図（左：1階，右：2 階) 
は, 床面積当たりの相当隙間面積（C 值）が建物全体で, I ・ II 地 域が $2 \mathrm{~cm}^{2} / \mathrm{m}^{2}$, III 〜 VI地域が $5 \mathrm{~cm}^{2} / \mathrm{m}^{2}$ となるように設定した。建物 全体の $\alpha \mathrm{A}$ から, 開口部の $\alpha \mathrm{A}$ を差し引いたものを, 開口部を除く外 皮の面積に応じて按分し，隙間は上下方向に 2 分割とした。

\section{3 伝熱・外表面の熱授受}

南側北側には日照の障害はないものとし（隣棟の影響を無視），東 側西側は隣接住戸が近接しており日照はないものとする。開口部の 日射遮蔽物として，レースカーテン（日射透過率 0.53）, 庇（屋根， バルコニー）を想定した。レースカーテンに関しては，透過率のみ 考慮し, 吸収率や反射率については考慮していない単純なモデルと した。日射吸収率は外壁面を 0.3 , 屋根面を 0.7 , 伝達形態は一定值 とし，長波長放射に関しては考慮しない。

\section{4 省エネルギー基準}

設定した各地域の熱損失係数 ( $\mathrm{Q}$ 值), 夏期日射取得係数 ( $\mu$ 值), 床面積当たりの相当隙間面積 (C 值), 建具の基準（気密性等級）を 表 6 に示す。なお, 表 6 の $\mathrm{Q}$ 值は換気量を一定值（換気回数 0.5 回 /h）として算出しており，文献 ${ }^{9)}$ の換気用熱回収装置による「3.9.2 (2)熱損失係数における換気回数の低減効果」は考慮していない。な お，建物モデルの作成数が小さくなるよう $\mathrm{Q}$ 值を設定しているため, $\mathrm{Q}$ 值は基準值よりも若干小さな值となっており, 暖房負荷は基準值 を使用して算出した值よりも小さくなることが予想される。

\section{4. 設備計画}

\section{1 全般換気設備}

図 4 に示寸ように, 全熱交換換気ユニットは 1 階ホールに設置 (G.L+2.9m), 1 階天井裏をダクトスペースとし, ユニットを通じて 各居室へ給気（1 階：天井吹出し，2 階：床吹出し）され, 内部扉 のアンダーカットを経由してホールから還気される。OA と EA の 外部への開放口（屋外端末）の設置高さは同一だが, 距離は十分離 れていることとし，EAが OAに与える影響（ショートサーキット） は無視する ${ }^{14)}$ 。全般換気設備の設計風量を表 7 に示す。必要換気量 は給気側で計画し, 換気対象室が換気回数 0.5 回/h 以上の給気量が 得られるように計画した。ホール 1 及びホール 2 は, 全般換気の換 気経路となるため居室と一体とみなし, ホール分の給気量を各居室 に振り分けている。給気量はダクト設計が容易になるように各居室 等しく設定し, 同時に各階への給気量も等しく設定した。なお, LDK は給気量が他居室に対して 2 倍となっているが，ダクトを 2 本設定 し，ダクト 1 本あたりの給気量を等しくした。同様に, 排気量の設 定に関しても，各階の排気量が等しくなるよう計画した。各室の給 排気経路長がなるべく等しくなるように計画し, 換気経路の圧力損 失を計算して与えている注 5)。

\section{2 局所換気設備}

レンジフードファンは, 後述の「5. 在室・内部発熱スケジュール」 に基づき, 調理していると思われる $2,000 \mathrm{~W}$ 程度の顕熱発熱がある ときに稼動するように設定し, 浴室天井扇については, 洗面所を使 用している時間帯及び浴室を使用している時間帯に連続して稼動す るようにし，就寝時に停止するよう設定する（図 5)。各ファンには それぞれ $\mathrm{PQ}$ 特性を与え, 逆止弁等の設置を想定し外気の流入はな いものとした。なお，便所パイプファンについては，在室・内部発 熱スケジュールからは運転状況が不明なことから運転しないものと
表 5 室内側・外気側の表面熱伝達抵抗

\begin{tabular}{|c|c|c|c|c|}
\hline 部位 & \multicolumn{2}{|c|}{$\begin{array}{c}\text { 室内側表面熱伝達抵抗 } \\
{\left[\mathrm{m}^{2} \mathrm{~K} / \mathrm{W}\right]} \\
\end{array}$} & \multicolumn{2}{|c|}{$\begin{array}{c}\text { 外気側表面熱伝達抵抗 } \\
{\left[\mathrm{m}^{2} \mathrm{~K} / \mathrm{W}\right]} \\
\end{array}$} \\
\hline 屋根 & \multicolumn{2}{|r|}{0.09} & \multicolumn{2}{|c|}{0.04} \\
\hline 天井 & \multicolumn{2}{|r|}{0.09} & \multicolumn{2}{|c|}{0.09} \\
\hline 外壁 & \multicolumn{2}{|r|}{0.11} & \multicolumn{2}{|c|}{0.04} \\
\hline 床 & \multicolumn{2}{|r|}{0.15} & \multicolumn{2}{|c|}{0.15} \\
\hline \multicolumn{5}{|c|}{ 表は文献9)のpp.138, 附表2に基づく } \\
\hline \multicolumn{5}{|c|}{ 表 6 省エネルギーの基準值と設定值 } \\
\hline $\begin{array}{l}\text { 地域 } \\
\text { 区分 }\end{array}$ & $\begin{array}{c}\mathrm{Q} \text { 值 } \\
{\left[\mathrm{W} / \mathrm{m}^{2} \mathrm{~K}\right]}\end{array}$ & $\begin{array}{l}\mu \text { 值 } \\
{[-]}\end{array}$ & $\begin{array}{c}\text { C值 } \\
{\left[\mathrm{cm}^{2} / \mathrm{m}^{2}\right]}\end{array}$ & $\begin{array}{c}\text { 建具の } \\
\text { 気密性等級 } \\
\end{array}$ \\
\hline $\begin{array}{l}\text { I } \\
\text { II }\end{array}$ & $\begin{array}{l}1.4(1.6 \text { 以下 }) \\
1.4(1.9 \text { 以下 })\end{array}$ & $0.04(0.08$ 以下 $)$ & 2.0 (2.0以下) & $\begin{array}{c}\mathrm{A}-4 \\
(\mathrm{~A}-4)\end{array}$ \\
\hline III & 2.1(2.4以下) & 0.04(0.07以下) & \multirow{3}{*}{ 5.0(5.0以下) } & \multirow{3}{*}{$\begin{array}{c}\mathrm{A}-3 \\
(\mathrm{~A}-3 \text { 又はA-4) }\end{array}$} \\
\hline $\begin{array}{l}\mathrm{IV} \\
\mathrm{V}\end{array}$ & 2.1(2.7以下) & 0.03(0.07以下) & & \\
\hline VI & 3.4(3.7以下) & 0.03(0.06以下) & & \\
\hline
\end{tabular}

表 7 全般換気設備の設計風量

\begin{tabular}{|c|c|c|c|c|c|c|c|}
\hline 階 & 室名 & 名称 & $\begin{array}{c}\text { 室容積 } \\
{\left[\mathrm{m}^{3}\right]}\end{array}$ & $\begin{array}{c}\text { 換気回数 } \\
{[\text { 回 } / \mathrm{h}]}\end{array}$ & $\begin{array}{c}\text { 必要給気量 } \\
{\left[\mathrm{m}^{3} / \mathrm{h}\right]}\end{array}$ & $\begin{array}{l}\text { 給気量 } \\
{\left[\mathrm{m}^{3} / \mathrm{h}\right]}\end{array}$ & $\begin{array}{l}\text { 排気量 } \\
{\left[\mathrm{m}^{3} / \mathrm{h}\right]}\end{array}$ \\
\hline \multirow{5}{*}{ 1階 } & 子供室1 & $\mathrm{BR} 1$ & 30.5 & 0.5 & 15.2 & 21 & - \\
\hline & 寝室 & MBR & 38.1 & 0.5 & 19.0 & 21 & - \\
\hline & 子供室2 & BR2 & 22.9 & 0.5 & 11.4 & 21 & - \\
\hline & ホール & Hall1 & 34.2 & 0.5 & 17.1 & - & 60 \\
\hline & \multicolumn{2}{|c|}{ 小 計 } & 125.7 & 0.5 & 62.8 & 63 & 60 \\
\hline \multirow{4}{*}{ 2階 } & 和室 & JR & 31.8 & 0.5 & 15.9 & 21 & - \\
\hline & $\mathrm{LD}+$ 台所 & LDK & 63.6 & 0.5 & 31.8 & 42 & - \\
\hline & ホール & Hall2 & 27.8 & 0.5 & 13.9 & - & 60 \\
\hline & \multicolumn{2}{|c|}{ 小 計 } & 123.2 & 0.5 & 61.6 & 63 & 60 \\
\hline \multicolumn{3}{|c|}{ 合 } & 248.9 & 0.5 & 124.4 & 126 & 120 \\
\hline
\end{tabular}

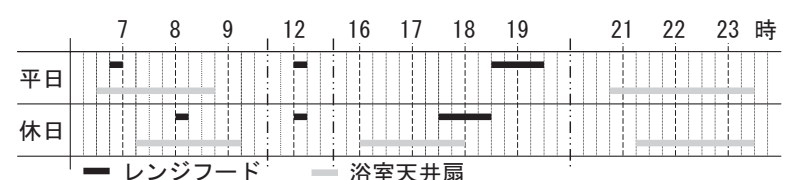

図 5 局所換気設備の運転スケジュール

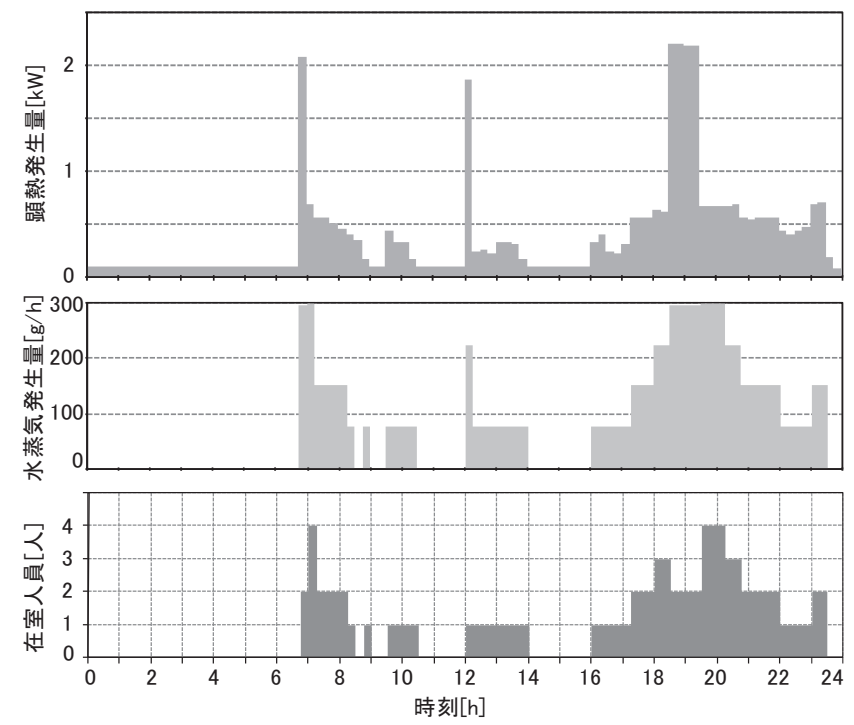

図 $6 \mathrm{LDK}$ の在室人員・内部発熱スケジュール (平日)

する。排気風量は, 台所 $300 \mathrm{~m}^{3} / \mathrm{h}$, 浴室 $80 \mathrm{~m}^{3} / \mathrm{h}$ とした。

\section{5. 在室・内部発熱スケジュール}

「自立循環型住宅開発委員会（B2）実証実験手法の開発と実施」 の研究成果 ${ }^{15)}$ をもとに作成（東京理科大学 長井達夫准教授）した 
表 8 冷暖房設備の能力

\begin{tabular}{c|c|c|c|c|c|c|c|c}
\hline \multirow{2}{*}{ 種別 } & \multirow{2}{*}{ 能 力 } & \multicolumn{3}{|c|}{ 居室 } & \multicolumn{4}{c}{ 非居室 } \\
\cline { 3 - 9 } & $\begin{array}{c}\text { 子供室 } 1 \cdot 2 \\
\text { 和室 }\end{array}$ & 寝室 & LDK & ホール1 & ホール2 & 洗面所 & 便所 \\
\hline \multirow{2}{*}{ 冷房 } & 冷房 $[\mathrm{kW}$ & 3.4 & 3.7 & 6.5 & - & - & - & - \\
\cline { 2 - 9 } & 除湿 $[\mathrm{L} / \mathrm{h}]$ & 1.4 & 1.6 & 3.6 & - & - & - & - \\
\hline 暖房 & 暖房[kW] & 6.2 & 7.7 & 9.8 & 3.2 & 2.3 & 0.7 & 0.35 \\
\hline
\end{tabular}

表 10 冷暖房設備の設定温湿度

\begin{tabular}{c|c|c}
\hline 状態 & 設備依存型 & 一般型 \\
\hline 冷房 & $26^{\circ} \mathrm{C}, 60 \% \mathrm{RH}$ & $26^{\circ} \mathrm{C}, 60 \% \mathrm{RH}$ or 通風 \\
(就寝時) & $28^{\circ} \mathrm{C}, 70 \% \mathrm{RH}$ & $28^{\circ} \mathrm{C}, 70 \% \mathrm{RH}$ or 通風 \\
\hline 暖房 & $22^{\circ} \mathrm{C}$ & $22^{\circ} \mathrm{C}$ or 通風 \\
(就寝時) & $18^{\circ} \mathrm{C}$ & - \\
\hline
\end{tabular}

暖房時の相対湿度はなりゆき

I ・II 地域における非居室の暖房設定温度は終日 $18^{\circ} \mathrm{C}$

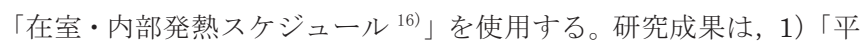
日スケジュール」及び「休日在室型スケジュール」，2）「行為と使 用機器の関連」，3）家電機器の運転スケジュール，4）調理に伴う 部屋への発熱量, 水蒸気発生量に関する実測結果, 5) 家電機器の 消費電力の日変動，6）部屋別照明器具の定格消費電力，7）一日の 電力消費量実測結果, から構成される。「在室・内部発熱スケジュー ル」は，この内の資料 1），2，4）のデータに基づいている。スケジ ュールは, 平日と休日（土, 日, 祝祭日）に分けられ, 室ごと, 15 分ごとの顕熱発熱量及び水蒸気発生量を設定している。図 6 に平日 の LDK の在室人員・内部発熱スケジュールを示す。就寝時は家電 機器により $100 \mathrm{~W}$ 程度の顕熱発熱が生じ, 炊事時間帯は照明器具・ 調理・在室人員・家電機器により 1900 $2200 \mathrm{~W}$ 程度の顕熱発熱と 調理・在室人員による $200 \sim 300 \mathrm{~g} / \mathrm{h}$ 程度の水蒸気発生が生じている。 通常の在室時は, 人員・行為・家電機器により $170 \sim 700 \mathrm{~W}$ 程度の 顕熱発熱と人員に応じた水蒸気発生が生じている。なお本研究では, 文献 15$)$ における和室を寝室に, 洋室 1 を子供室 1 に, 洋室 2 を子供 室 2 に置き換えている。

\section{6. 計算モデルと冷暖房・通風 \\ 6.1 冷暖房設備の能力}

冷暖房設備の能力を表 8 に示す。冷房時は除湿を想定するが，暖 房時の加湿は想定しない。

\section{2 計算モデル・モード}

計算モデルとして，都市部を想定し，立地条件などから清掃以外 は空開け換気 (通風) を行わない「設備依存型」, 冷暖房に標準的と 思われる通風を加え, 就寝時の暖房を取り止めた「一般型」を作成 した（表 9）。空の開閉条件は冷房負荷に, 就寝時の暖房設定は暖房 負荷に大きな影響を与えるが，ここではある特定の条件を想定し， 冷暖房負荷の抑制効果を考察する。

\section{3 冷暖房設備の設定温室度・発停条件}

冷暖房の設定温湿度, とりわけ冷房時の室温・発停・通風の設定 は冷房負荷に大きな影響を及ぼす。設定温度に関しては $26 \sim 28^{\circ} \mathrm{C}$ 程 度と報告されているが ${ }^{17)}$, 典型的な冷房の使い方は存在しない。こ こでは冷暖房運転の温湿度設定を表 10 とし，発停は「在室・内部 発熱スケジュール」に基づく（一時的な 30 分未満の退出時には停 止しない)。冷暖房対象室について, I ・ II 地域は全室暖房, 他の地
表 9 計算モデルと開口部の状態

\begin{tabular}{|c|c|c|c|c|c|c|}
\hline \multirow{2}{*}{ 開口種類 } & \multicolumn{3}{|c|}{ 一般型 } & \multicolumn{3}{|c|}{ 設備依存型 } \\
\hline & 通常 & 掃除 ${ }^{\dagger 2}$ & 就寝 & 通常 & 掃除 ${ }^{\dagger 2}$ & 就寝 \\
\hline 風上開口 ${ }^{\dagger 1}$ & 空全開 & 空全開 & 就寝開 ${ }^{\dagger 3}$ & 空閉 & 空全開 & 空閉 \\
\hline 間仕切り & 扉閉 & 扉閉 & 扉閉 & 扉閉 & 扉閉 & 扉閉 \\
\hline 風下開口 ${ }^{\dagger 1}$ & 空全開 & 空全開 & 就寝開 ${ }^{\dagger 3}$ & 空閉 & 空全開 & 空閉 \\
\hline
\end{tabular}

${ }^{\dagger}$ 「風上開口」，「風下開口」は，共に同一室の開口。

†「掃除」とは LD 及び寝室の清掃を指し, 台所の空は清掃時 「開」, 通風（通常及び就寝時の空開け）時「閉」とする。

† 3 「就寝開」とは，空を片側 $25 \mathrm{~cm}$ 開けた状態とする。 通風時の空の相当開口面積は, 開口面積に網戸の流量係数 0.5 を乗じる。また, 清掃時の空の流量係数は 0.65 とする。 通風に関しては, 就寝時を除き, 冷房期は外気温が $20 \sim 25^{\circ} \mathrm{C}$ の時に空を開け，暖房期は外気温が $18 \sim 26^{\circ} \mathrm{C}$ の時に空を開け 通風をとることにする。

冷房期の就寝時の通風に関しては，外気温が $25 \sim 28^{\circ} \mathrm{C}$ の時 に行う。

域は在室している居室の夕暖房し, 冷房に関しては全地域在室して いる居室のみ冷房する。また，暖房期間以外を冷房期間として冷房 のみを行い，室温が暖房設定温度より下がっても暖房は行わない。

\section{4 全熱交換器の設置を想定しないモデル}

全熱交換器設置の有無による冷暖房負荷の違いを確認するために, 全熱交換器の設置を想定しないモデルを作成した。換気方式を変更 すると換気性状も変化し, 機械換気量や隙間風量, 隣室への熱損失 など，冷暖房負荷自体が異なり，全熱交換器の導入効果を評価する ことは困難である。そこで，同一の換気方式とし，図 1 の換気回路 網モデルにおいて, 給気系 $(\mathrm{OA}-\mathrm{SA})$ から排気系 $(\mathrm{RA}-\mathrm{EA})$ 一熱・水 蒸気・空気の移動がないことを想定した。熱・水蒸気回路網モデル においては, 熱交換素子の一般化熱コンダクタンス及び一般化湿気 コンダクタンス（図 3 のコンダクタンス 3-15，4-14，5-13，6-12， 7-11）を，それぞれ $0 \mathrm{~W} / \mathrm{K}, 0 \mathrm{~kg} / \mathrm{s}(\mathrm{kg} / \mathrm{kg})$ とした。また，熱交換素子 移流（図 1 の流路 $22,23,24,25,26$ ）を閉じる設定とした。

\section{5 全熱交換器のエンタルピー制御}

夏期の冷涼な日や夜間，中間期においては，内部発熱や日射によ る受熱，室間の影響など，建物全体システムの挙動により，還気エ ンタルピーが外気エンタルピーを上回り，熱回収が逆効果になる場 合が予想される。そのため, 還気エンタルピーが外気エンタルピー を超える場合は，給気系である OA-SA 系統において，熱交換素子 を通過しないバイパス経路を想定した (図 1 , 表 1 )。図 1 において, バイパス回路（流路 27）が開いた時には，通常の流路（流路 3）が 閉じる設定としている。

\section{7. 温暖地域（東京）における全熱交換器の導入効果}

本報では，特に寒冷地での暖房負荷の抑制効果が期待されている 全熱交換器を, 温暖地（東京）の戸建住宅に採用した場合の導入効 果と利用法ついて検討する。「設備依存型」は，「全熱交換器あり」 (以降, 熱交あり),「全熱交換器なし」（以降，熱交なし）及び「全 熱交換器あり エンタルピー制御」（以降，熱交あり エンタルピー 制御）を計算し，「一般型」は「熱交あり」のみ計算した。暖房期と 冷房期に関しては, 日平均気温が $15^{\circ} \mathrm{C}$ 以下になる期間を算出して暖 房期間とし，暖房期間以外は冷房期間として設定した（冷暖房設備 の発停条件は 6.3 による)。計算助走期間は 3 日間, 計算時間間隔は 15 分, 熱回路網・水蒸気回路網共に非定常計算とする。 
表 11 年間冷暖房負荷計算結果

\begin{tabular}{|c|c|c|c|c|c|c|c|c|c|c|c|c|c|c|c|c|c|c|}
\hline \multirow{2}{*}{$\begin{array}{c}\begin{array}{c}\text { 地域区分 } \\
\text { (地点) }\end{array} \\
\end{array}$} & \multirow{2}{*}{\multicolumn{2}{|c|}{$\begin{array}{l}\text { 計算 } \\
\text { モデル }\end{array}$}} & \multirow{2}{*}{\multicolumn{2}{|c|}{ 計算条件 }} & \multicolumn{12}{|c|}{ 月積算值[MJ] } & \multirow{2}{*}{$\begin{array}{c}\text { 年積算值 } \\
{[\mathrm{MJ}]}\end{array}$} & \multirow{2}{*}{$\begin{array}{c}\text { 暖冷房 } \\
\text { 年積算值 }\end{array}$} \\
\hline & & & & & \multirow{2}{*}{$\begin{array}{l}\text { 1月 } \\
4470\end{array}$} & \multirow{2}{*}{\begin{tabular}{|c|}
2 月 \\
3735
\end{tabular}} & \multirow{2}{*}{$\begin{array}{c}3 \text { 月 } \\
3395\end{array}$} & \multirow{2}{*}{$\begin{array}{l}\text { 4月 } \\
831\end{array}$} & \multirow{2}{*}{$\begin{array}{r}\text { 月月 } \\
0\end{array}$} & \multirow{2}{*}{$\begin{array}{r}\text { 6月 } \\
0\end{array}$} & \multirow{2}{*}{$\begin{aligned} 7 \text { 月 } \\
0\end{aligned}$} & \multirow{2}{*}{$\begin{array}{r}\text { 8月 } \\
0\end{array}$} & \multirow{2}{*}{\begin{tabular}{r|} 
9月 \\
0
\end{tabular}} & \multirow{2}{*}{$\begin{array}{r}10 \text { 月 } \\
220\end{array}$} & \multirow{2}{*}{$\begin{array}{l}11 \text { 月 } \\
1492\end{array}$} & \multirow{2}{*}{$\begin{array}{l}12 \text { 月 } \\
3110\end{array}$} & & \\
\hline \multirow{26}{*}{$\begin{array}{l}\text { IV } \\
\text { 地 } \\
\text { 域 } \\
\text { 東 } \\
\text { 京 }\end{array}$} & \multirow{16}{*}{$\begin{array}{l}\text { 設 } \\
\text { 備 } \\
\text { 依 } \\
\text { 存 } \\
\text { 型 }\end{array}$} & \multirow{4}{*}{ a 熱交なし } & 暖房 & 顕熱 & & & & & & & & & & & & & 17252 & 26471 \\
\hline & & & \multirow{3}{*}{ 冷房 } & 顕熱 & 0 & 0 & 0 & 52 & 337 & 575 & 2191 & 2385 & 1190 & 370 & 24 & 0 & 7124 & [MJ] \\
\hline & & & & 潜熱 & 0 & 0 & 0 & 5 & 5 & 139 & 659 & 881 & 369 & 37 & 0 & 0 & 2095 & 217 \\
\hline & & & & 全熱 & 0 & 0 & 0 & 57 & 343 & 714 & 2851 & 3266 & 1559 & 407 & 24 & 0 & 9219 & {$\left[\mathrm{MJ} / \mathrm{m}^{2}\right]$} \\
\hline & & \multirow{4}{*}{\begin{tabular}{l|l} 
旨 & b 熱交あり \\
&
\end{tabular}} & 暖房 & 顕熱 & 4056 & 3380 & 3064 & 718 & 0 & 0 & 0 & 0 & 0 & 194 & 1292 & 2790 & 15494 & \multirow{6}{*}{$\begin{array}{c}24748 \\
{[\mathrm{MJ}]} \\
203 \\
{\left[\mathrm{MJ} / \mathrm{m}^{2}\right]}\end{array}$} \\
\hline & & & \multirow{3}{*}{ 冷房 } & 顕熱 & 0 & 0 & 0 & 60 & 377 & 634 & 2228 & 2423 & 1227 & 400 & 28 & 0 & 7378 & \\
\hline & & & & 潜熱 & 0 & 0 & 0 & 5 & 9 & 145 & 582 & 761 & 336 & 38 & 0 & 0 & 1876 & \\
\hline & & & & 全熱 & 0 & 0 & 0 & 66 & 386 & 779 & 2810 & 3184 & 1563 & 438 & 28 & 0 & 9254 & \\
\hline & & \multicolumn{3}{|c|}{ 負荷比 $\left(\mathrm{b} / \mathrm{a}^{*} 100\right)[\%]$} & 90.7 & 90.5 & 90.3 & 88.3 & 112.6 & 109.2 & 98.6 & 97.5 & 100.3 & 100.9 & 87.1 & 89.7 & 93.5 & \\
\hline & & 負荷低減量 & $a-b)[M$ & & 414 & 355 & 331 & 104 & -43 & -66 & 41 & 81 & -4 & -5 & 196 & 319 & 1723 & \\
\hline & & & 暖房 & 顕熱 & 4056 & 3380 & 3064 & 718 & 0 & 0 & 0 & 0 & 0 & 194 & 1292 & 2790 & 15494 & \\
\hline & & c 熱交あり & & 顕熱 & 0 & 0 & 0 & 52 & 340 & 581 & 2201 & 2405 & 1200 & 371 & 24 & 0 & 7174 & 24512 \\
\hline & & ピー制御 & 冷房 & 潜熱 & 0 & 0 & 0 & 5 & 5 & 136 & 575 & 758 & 329 & 36 & 0 & 0 & 1844 & [MJ] \\
\hline & & & & 全熱 & 0 & 0 & 0 & 57 & 346 & 716 & 2776 & 3162 & 1529 & 408 & 24 & 0 & 9018 & 201 \\
\hline & & 負荷比 $\left(\mathrm{c} / \mathrm{a}^{*}\right.$ & $100)[\%$ & & 90.7 & 90.5 & 90.3 & 87.3 & 100.9 & 100.4 & 97.4 & 96.8 & 98.1 & 96.1 & 86.8 & 89.7 & 92.6 & {$\left[\mathrm{MJ} / \mathrm{m}^{2}\right]$} \\
\hline & & 負荷低減量 & $\left.\mathrm{a}^{-\mathrm{c}}\right)[\mathrm{M}$ & & 414 & 355 & 331 & 113 & -3 & -3 & 75 & 103 & 30 & 25 & 200 & 319 & 1959 & \\
\hline & & & 暖房 & 顕熱 & 3345 & 2555 & 2373 & 577 & 0 & 0 & 0 & 0 & 0 & 182 & 990 & 2138 & 12162 & \\
\hline & & & & 顕熱 & 0 & 0 & 0 & 21 & 91 & 95 & 1951 & 2242 & 963 & 142 & 19 & 0 & 5525 & 19136 \\
\hline & & (v) & 冷房 & 潜熱 & 0 & 0 & 0 & 0 & 1 & 11 & 479 & 683 & 260 & 15 & 0 & 0 & 1450 & [MJ] \\
\hline & & & & 全熱 & 0 & 0 & 0 & 21 & 92 & 106 & 2430 & 2926 & 1223 & 157 & 19 & 0 & 6975 & 157 \\
\hline & \begin{tabular}{|l|} 
般 \\
型
\end{tabular} & 負荷比 $(\mathrm{d} / \mathrm{a}$ * & 100) $[\%$ & & 74.8 & 68.4 & 69.9 & 67.5 & 26.8 & 14.8 & 85.2 & 89.6 & 78.5 & 54.2 & 66.6 & 68.8 & 72.3 & {$\left[\mathrm{MJ} / \mathrm{m}^{2}\right]$} \\
\hline & & 負荷低減量 & $a-d)[M$ & & 1125 & 1180 & 1021 & 289 & 251 & 608 & 421 & 340 & 335 & 287 & 506 & 971 & 7334 & \\
\hline & & 負荷比 $\left(\mathrm{d} / \mathrm{b}^{*}\right.$ & 100) $[\%$ & & 82.5 & 75.6 & 77.5 & 76.4 & 23.8 & 13.6 & 86.5 & 91.9 & 78.3 & 53.7 & 76.5 & 76.6 & 77.3 & \\
\hline & & 負荷低減量 & $b-d)[M$ & & 712 & 825 & 691 & 184 & 294 & 673 & 380 & 258 & 340 & 293 & 310 & 652 & 5612 & \\
\hline & & 給気 $(\mathrm{SA})$ 風 & {$\left[\mathrm{m}^{3} / \mathrm{h}\right.$} & & 135 & 135 & 135 & 136 & 136 & 136 & 136 & 136 & 136 & 136 & 136 & 135 & & \\
\hline & & 建物全体換気 & 句数 [回 & {$[/ \mathrm{h}]$} & 0.96 & 0.97 & 0.95 & 0.89 & 0.86 & 0.83 & 0.79 & 0.80 & 0.78 & 0.82 & 0.89 & 0.90 & & 0 \\
\hline
\end{tabular}

\section{1 用語の定義}

全熱交換器の冷暖房負荷抑制効果を評価する上で，本研究で用い る用語を以下のように定義する。

負荷比 [\%]：例えば，「熱交あり」の「熱交なし」に対する暖房負 荷又は冷房負荷の比。

負荷低減率 [\%]：100一負荷比

負荷低減量 $[\mathrm{MJ}]$ : 例えば，「熱交なし」と「熱交あり」の暖房負 荷又は冷房負荷の差。

各モデルの地域で共通である内部発熱や日射による受熱が冷暖房 負荷に与える影響が大きいため, 負荷低減量に対して負荷比が過大 評価となる恐れがある。そのため, 全熱交換器による冷暖房負荷の 抑制効果を, 相対值である負荷比（又は負荷低減率）と併せて, 絶 対值である負荷低減量で評価する。

同時に, 通風・換気性状を評価する用語を以下のように定義する。

建物全体換気回数 [回/h]：モデル化した空間（建物全体）に流入 する新鮮外気量 $\left[\mathrm{m}^{3} / \mathrm{h}\right]$ の合計值を, 建物全体の気積 $\left[\mathrm{m}^{3}\right]$ で除した值。 季節毎の自然換気量の変動を考察するために用いる。本研究では, 小屋裏・床下空間も建物全体の気積に含んでいる。

気流通過率 $[$ 回/h]: 換気回数がその室への新鮮外気量をその室の 気積で除した值であるのに対し，気流通過率は，その室へ流入する 新鮮外気量と他室経由の風量を合わせた風量 $\left[\mathrm{m}^{3} / \mathrm{h}\right]$ をその室の気積 で除した值。

気流通過率は, 評価対象室の污染質発生量と濃度から求められる 新鮮外気量換算值である実効換気量 ${ }^{18)}$ のように換気評価に適した 指標でないが，換気回数と比較することにより，その室の換気性状 の評価に利用できる。

\section{2 冷暖房負荷抑制効果とコールドドラフトの緩和}

年間冷暖房負荷計算表を表 11 に示す。「設備依存型」における「a

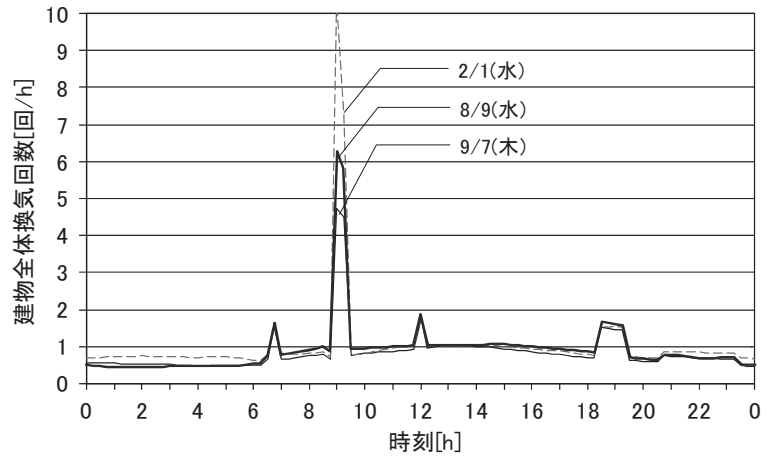

図 7 建物全体換気回数の変移（設備依存型， b 熱交あり）

熱交なし」と「b 熱交あり」を比較し，全熱交換器の冷暖房負荷抑 制効果について検討する。「設備依存型」における「b 熱交あり」 の給気 $(\mathrm{SA})$ 風量は $135 \mathrm{~m}^{3} / \mathrm{h}$ 程度 (換気対象室に対する換気回数 0.54 回/h）でほとんど変動しないが，室内外温度差や外部風圧力などの 外乱により，建物全体換気回数は変動する。建物全体換気回数の変 移は時刻ごとにみるとさらに顕著になるが（図 7)，全熱交換換気ユ ニットの給排気量はほとんど変化しない。

室内外温度差の大きい 12 月及び 1 ～ 3 月の冬期には，10\%程度の 暖房負荷の低減率が見られる。「設備依存型」における $2 / 1$ (水)のユ ニット内の温度変化を図 8 左に示す。還気 $(\mathrm{RA})$ と外気 $(\mathrm{OA})$ の温度差 $(\mathrm{RA}-\mathrm{OA})$ は，最大で $10.9^{\circ} \mathrm{C}$, 最小で $4.9^{\circ} \mathrm{C}$, 平均で $8.4^{\circ} \mathrm{C}$ なって いる。給気 $(\mathrm{SA})$ 温度から，特に外気温が低い時に給気によるコール ドドラフトが緩和され, 温熱環境が改善されている。なお， 11 月は $10 \%$ 以上暖房負荷の低減率が見られるが，低減量は小さい。

夏期である $7 \cdot 8$ 月は, 2 \% $3 \%$ 程度の冷房負荷の低減率となる。「設 備依存型」における $8 / 9$ (水)のユニット内の温度変化を図 8 中央に示 す。 $\mathrm{RA}$ と $\mathrm{OA}$ の温度差 $(\mathrm{OA}-\mathrm{RA})$ は, 最大で $2.3^{\circ} \mathrm{C}$, 最小では $\mathrm{OA}<\mathrm{RA}$ 

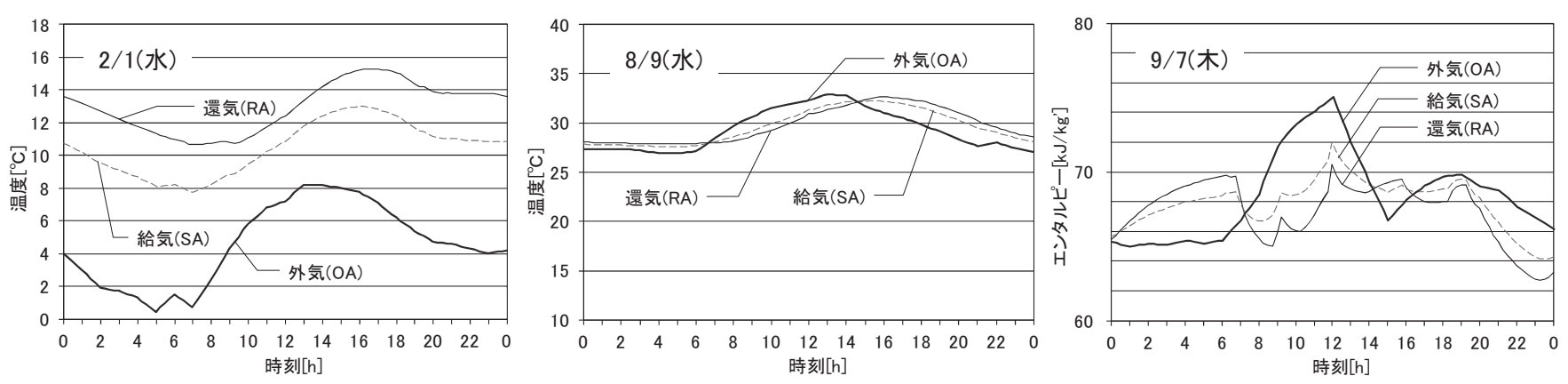

図 8 全熱交換換気ユニット内の温度・エンタルピー变化（設備依存型，b 熱交あり）

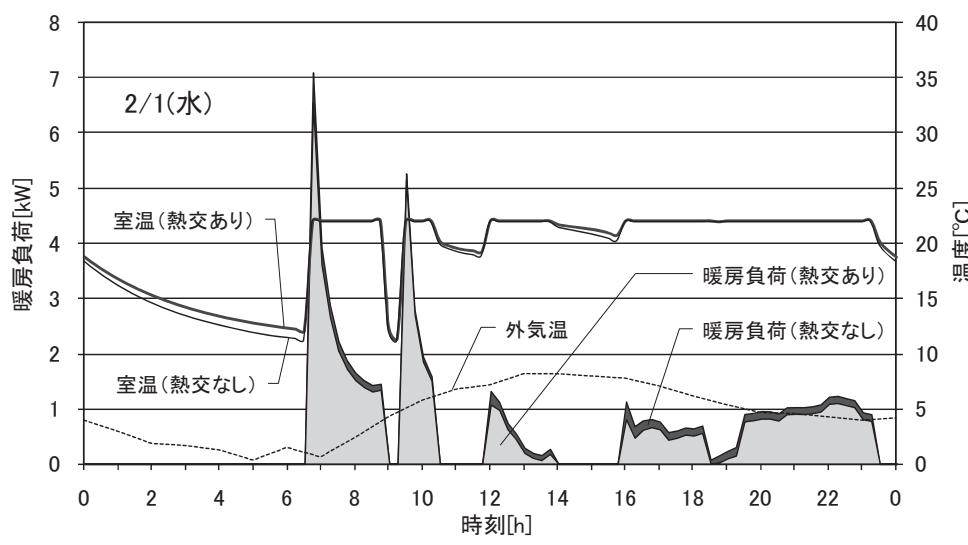

図 $9 \mathrm{LDK}$ の室温・暖房負荷（設備依存型）

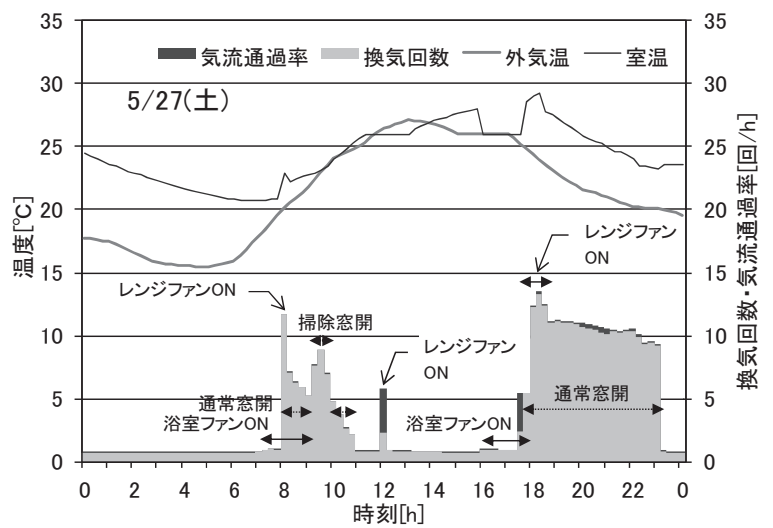

図 $10 \mathrm{LDK}$ の室温・気流通過率・換気回数 (一般型)
となり $-2.8^{\circ} \mathrm{C}$, 平均で $-0.5^{\circ} \mathrm{C}$ とっている。夏期は, 外気温度と 還気温度の差が小さく, 還気温度が外気温度を上回っている時間帯 が多い。

中間期の 5〜6 月及び 9〜10 月には負荷比が 100\%を超え，全熱 交換器が逆効果となっている。特に 5 月は泠房期であるが, 全熱交 換器を設置することにより $10 \%$ 以上冷房負荷が増加している。中間 期の泠房日には，夏期の夕刻〜朝方と同様，内部発熱や日射による 受熱, 室間の影響など, 建物全体システムの挙動で, 還気エンタル ピーが外気エンタルピーを上回り (図 8 右), 熱回収が逆効果にな っているためである。夏期の 7〜8 月に関しても同様の現象から, 外気と還気のエンタルピー差が小さく, 日時によっては逆転してし まう場合があるため, 全熱交換器の設置による冷房負荷の低減はほ とんど見られず， $2 \%$ 程度の冷房負荷の低減率となった。

\section{3 エンタルピー制御した全熱交換器の冷暖房負荷抑制効果}

熱回収が逆効果になる場合があることから, エンタルピー制御を 持つ全熱交換換気ユニットを想定した。表 11 の「設備依存型」に おける「 $\mathrm{a}$ 熱交なし」と「c 熱交ありエンタルピー制御」を比較し, 冷暖房負荷の抑制効果について検討する。

$5 \cdot 6$ 月の負荷比を見ると, $1 \%$ 未満であるが「 $\mathrm{a}$ 熱交なし」と比 較して冷房負荷が増加している。これは, ユニットのバイパス回路 （図 1 の流路 27）が開いた時には通常の流路（図 1 の流路 3) が閉 じる設定としたが, 想定したユニットのモデルは給気系(OA-SA)経 路の圧力が排気系(RA-EA)経路の圧力より低いため, 僅かであるが 排気系空気が流路 22〜26 を経て給気系空気一と混入しているため である。排気系空気が給気系空気に混入してしまう今回のようなモ デルでは, 還気エンタルピーが外気エンタルピーを上回る冷房日に おいて, 予想される空気質の悪化に加えて冷房負荷も増加する。7・
8 月は「 $\mathrm{a}$ 熱交なし」と比較して $3 \%$ 程度, 「 $\mathrm{b}$ 熱交あり」と比較し ても $1 \%$ 程度の泠房負荷の低減率となる。

\section{4 暖房負荷と室温}

図 9 に「設備依存型」のLDK の室温・暖房負荷を示す。LDK は, 南面と東面に外壁が配置される $\mathrm{LD}$ と, 東面と北面に外壁が配置さ れる台所からなる 2 階の居室である。床面積が大きく, 使用時間帯 も多く, 在室人員も多い。9 時過ぎに室温が低いのは, 清掃時の空 開けによるものである。朝の外気温が低いときに暖房が立ち上がり， 暖房負荷がピークとなる。冷暖房設備の運転時間が長く, 室温が安 定している時に全熱交換器の冷暖房負荷抑制効果が高い。

\section{5 通風と就寝時の暖房取り止めによる冷暖房負荷抑制効果}

表 11 の冷房負荷の年積算值は, 統計 ${ }^{19)}$ や実態調查 ${ }^{20)}$, 21) と大きな 開きがあるが，これは冷房の使用実態がシミュレーションと異なる

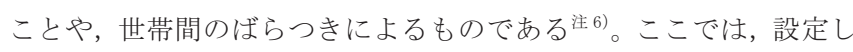
た条件で空開閉を行った居室の室温・気流通過率・換気回数を考察 することにより, モデルの妥当性の検証を行う。「一般型」における $5 / 27$ (土)の LDK の室温・気流通過率を図 10 に示寸。外気温は, 最 低 $15.5^{\circ} \mathrm{C}$, 最高 $27.1^{\circ} \mathrm{C}$, 平均 $21.3^{\circ} \mathrm{C}$ で, $11: 30 \sim 13: 00$ 及び $16: 00$ 〜 17:30 は冷房制御が働いている。清掃空明けを行っている時間帯 の室温は外気温に近い。換気回数と気流通過率の関係から, LDKに 流入するのはほとんどが新鮮外気であるが，空閉の状態でレンジフ ードファンを稼動させると, ホールや和室からの流入風量が増加す る。朝方の清掃空明け・通風時は外部風速（軒高）：0.5 $1.5 \mathrm{~m} / \mathrm{s}$, 風向: $\mathrm{N} \cdot \mathrm{NNE} \cdot \mathrm{NNW}$, 気流通過率は清掃空明け時で $7 \sim 9$ 回/h 程度, 通風時で $3 \sim 7$ 回/ $\mathrm{h}$ 程度となった。また, 夕刻から夜間の通 風を行っている時間帯は, 外部風速（軒高）: $1.5 \sim 2.1 \mathrm{~m} / \mathrm{s}$, 風向 : $\mathrm{S} \cdot \mathrm{SSW}$, 気流通過率は 9 11 回/h 程度となった。 
表 12 断熱・気密性能の異なる建物の年間冷暖房負荷計算結果

\begin{tabular}{|c|c|c|c|c|c|c|c|c|c|c|c|c|}
\hline \multirow{2}{*}{$\begin{array}{l}\text { 地域区分 } \\
\text { (地点) }\end{array}$} & \multirow{2}{*}{\multicolumn{3}{|c|}{$\begin{array}{c}\text { 断熱・気密性能 } \\
\text { 計算モデル }\end{array}$}} & \multirow{2}{*}{\multicolumn{2}{|c|}{ 計算条件 }} & \multicolumn{5}{|c|}{ 期間積算值[MJ] } & \multirow{3}{*}{$\begin{array}{c}\begin{array}{c}\text { 年積算值 } \\
{[\mathrm{MJ}]}\end{array} \\
17252\end{array}$} & \multirow{2}{*}{$\begin{array}{c}\text { 暖冷房 } \\
\text { 年積算値 }\end{array}$} \\
\hline & & & & & & 1-3月 & 4月 & 5-9月 & 10-11月 & 12月 & & \\
\hline & \multirow{9}{*}{$\begin{array}{c}\mathrm{C} \text { 值 } \\
5.0 \mathrm{~cm}^{2} / \mathrm{m}^{2} \\
\text { Q值 } \\
2.1 \mathrm{~W} / \mathrm{m}^{2} \mathrm{~K}\end{array}$} & \multirow{4}{*}{\multicolumn{2}{|c|}{ a 熱交なし }} & 暖房 & \begin{tabular}{|l|} 
顕熱 \\
\end{tabular} & 11600 & 831 & 0 & 1712 & 3110 & & \multirow{4}{*}{$\begin{array}{c}26471 \\
{[\mathrm{MJ}]} \\
217 \\
{\left[\mathrm{MJ} / \mathrm{m}^{2}\right]}\end{array}$} \\
\hline & & & & \multirow{3}{*}{ 冷房 } & \begin{tabular}{|l|l} 
顕熱 \\
\end{tabular} & 0 & 52 & 6678 & 394 & 0 & 7124 & \\
\hline & & & & & \begin{tabular}{|l|} 
潜熱 \\
\end{tabular} & 0 & 5 & 2053 & 37 & 0 & 2095 & \\
\hline & & & & & 全熱 & 0 & 57 & 8731 & 431 & 0 & 9219 & \\
\hline & & & \multirow{4}{*}{ | b 熱交あり } & 暖房 & \begin{tabular}{|l|} 
顕熱 \\
\end{tabular} & 10500 & 718 & 0 & 1486 & 2790 & 15494 & \multirow{5}{*}{$\begin{array}{c}24748 \\
{[\mathrm{MJ}]} \\
203 \\
{\left[\mathrm{MJ} / \mathrm{m}^{2}\right]}\end{array}$} \\
\hline & & & & \multirow{3}{*}{ 冷房 } & \begin{tabular}{|l|l} 
顕熱 \\
\end{tabular} & 0 & 60 & 6890 & 428 & 0 & 7378 & \\
\hline & & & & & \begin{tabular}{|l|} 
潜熱 \\
\end{tabular} & 0 & 5 & 1832 & 38 & 0 & 1876 & \\
\hline & & 設 & & & 全熱 & 0 & 66 & 8722 & 466 & 0 & 9254 & \\
\hline & & $\begin{array}{l}\text { 偏 } \\
\text { 依 }\end{array}$ & 負荷比 (b/ & $a * 100$ & ) $[\%]$ & 90.5 & 88.3 & 99.9 & 91.1 & 89.7 & 93.5 & \\
\hline & \multirow{9}{*}{$1.4 \mathrm{~W}$} & \begin{tabular}{|l|} 
依 \\
存
\end{tabular} & \multirow{4}{*}{ c 熱交なし } & 暖房 & \begin{tabular}{|l|} 
顕熱 \\
\end{tabular} & 7541 & 478 & 0 & 940 & 1958 & 10916 & \multirow{4}{*}{$\begin{array}{c}20584 \\
{[\mathrm{MJ}]} \\
169 \\
{\left[\mathrm{MJ} / \mathrm{m}^{2}\right]}\end{array}$} \\
\hline & & 型 & & \multirow{3}{*}{ 冷房 } & \begin{tabular}{|l|} 
顕熱 \\
\end{tabular} & 0 & 83 & 6911 & 521 & 0 & 7515 & \\
\hline & & & & & \begin{tabular}{|l|l} 
潜熱 \\
\end{tabular} & 0 & 5 & 2106 & 40 & 0 & 2152 & \\
\hline & & & & & 全熱 & 0 & 88 & 9017 & 562 & 0 & 9667 & \\
\hline & & & \multirow{4}{*}{ d 熱交あり } & 暖房 & \begin{tabular}{|l|l} 
顕熱 \\
\end{tabular} & 6186 & 355 & 0 & 686 & 1576 & 8803 & \multirow{5}{*}{$\begin{array}{c}18662 \\
{[\mathrm{MJ}]} \\
153 \\
{\left[\mathrm{MJ} / \mathrm{m}^{2}\right]}\end{array}$} \\
\hline & & & & \multirow{3}{*}{ 冷房 } & \begin{tabular}{|l|} 
顕熱 \\
\end{tabular} & 0 & 106 & 7250 & 602 & 0 & 7958 & \\
\hline & & & & & \begin{tabular}{|l|} 
潜熱 \\
\end{tabular} & 0 & 7 & 1851 & 43 & 0 & 1902 & \\
\hline & & & & & 全熱 & 0 & 113 & 9101 & 645 & 0 & 9859 & \\
\hline & & & \multicolumn{3}{|c|}{ 負荷比 $\left(\mathrm{d} / \mathrm{c}^{*} 100\right)[\%]$} & 82.0 & 82.8 & 100.9 & 88.7 & 80.5 & 90.7 & \\
\hline & \multicolumn{5}{|c|}{ 負荷比 (c/a*100)[\%] } & 65.0 & 63.8 & 103.3 & 70.1 & 63.0 & 77.8 & \\
\hline & & & \multicolumn{3}{|c|}{ 負荷比(d/b*100) [\%] } & 58.9 & 59.8 & 104.3 & 68.2 & 56.5 & 75.4 & \\
\hline & & & \multicolumn{3}{|c|}{ 負荷比 $(\mathrm{d} / \mathrm{a}$ *100) [\%] } & 53.3 & 52.8 & 104.2 & 62.1 & 50.7 & 70.5 & \\
\hline
\end{tabular}

表 11 の「設備依存型」における「b 熱交あり」と「一般型」に おける「d 熱交あり」を比較し, 通風時及び就寝時の暖房設定変更 による冷暖房負荷の抑制効果について検討する。 12 月及び $1 \sim 3$ 月 は清掃時を除き空明けは行っていないことから, 各月 $20 \%$ 前後, 暖 房期間で $22 \%$ の暖房負荷の低減率は, 就寝時の暖房制御 $\left(18^{\circ} \mathrm{C}\right)$ の 取り止めによるものである。5〜 6 月及び 10 月は冷房負荷の低減率 が $45 \%$ 超えているが，低減量でみれば 5 月及び 10 月は月間で $300 \mathrm{MJ}$ 程度となっており，7 月及び 8 月と大差がない。7〜9 月は 通常の空明けに加えて就寝時の空明けも行っており，10～20\%程度 の冷房負荷の低減率となった。また，冷房期である $5 \sim 9$ 月の冷房

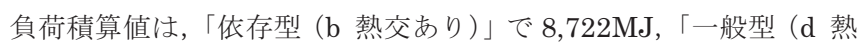
交あり)」で $6,777 \mathrm{MJ}$ となっており, 空明け通風により $22 \%$ 冷房 負荷の低減率がみられる。実態調査 ${ }^{20)}$ において, 暑さを感じた際に 空開け行動と扇風機等の使用をする行動パターンは, エアコンのみ を使用する行動パターンと比較して, 冷房消費エネルギーが $30 \%$ 弱 少ないと報告されている。

\section{8. 建物の断熱・気密性能向上時の冷暖房負荷抑制効果}

住宅の省エネルギーの基準值の内，断熱・気密性能を向上させた 場合の泠暖房負荷の抑制効果について考察する。建物の断熱・気密 性能を, IV 地域の仕様から I 地域の仕様（表 6）に変更した。C 值 を $5.0 \mathrm{~cm}^{2} / \mathrm{m}^{2}$ から $2.0 \mathrm{~cm}^{2} / \mathrm{m}^{2}, \mathrm{Q}$ 值を $2.1 \mathrm{~W} / \mathrm{m}^{2} \mathrm{~K}$ から $1.4 \mathrm{~W} / \mathrm{m}^{2} \mathrm{~K}$ 一 と向上させた。冷暖房負荷計算結果を表 12 に示寸。計算モデルは 清掃時以外空開け換気を行わない「設備依存型」を使用し，それぞ れの断熱・気密仕様において「熱交あり」,「熱交なし」について計 算を行った。

\section{1 全熱交換器による冷暖房負荷抑制効果の変化}

各断熱・気密性能向上による全熱交換器の冷暖房負荷抑制効果の 変化は, 表 12 の冷暖房負荷比 $\mathrm{b} / \mathrm{a}$ と d/c を比較することで評価する。 通年でみると, 冷暖房負荷の低減率が $6.5 \%$ か 9.3\%に若干である が向上している。これは, 外皮からの熱損失が小さくなり, 換気に
よる熱損失の割合が大きくなり, 全熱交換器の効果が大きくなった ことによるものである。期間ごとにみると，暖房期間における全熱 交換器の負荷低減率は大きいが, 冷房期間には逆に負荷比が増加し ている。建物の保温性能が向上したことにより,「設備依存型」のよ うな通風を想定していないモデルでは外部に熱が逃げにくく, 内部 発熱や日射受熱等の影響により室温が外気温より高くなり，全熱交 換器が熱回収してしまうことが原因と考えられる。

\section{2 断熱・気密性能向上による冷暖房負荷抑制効果}

断熱・気密性能向上による建物の冷暖房負荷抑制効果は，表 12 の冷暖房負荷比 $\mathrm{c} / \mathrm{a}$ 又は $\mathrm{d} / \mathrm{b}$ で評価できる。c/a を通年でみると, 暖 房負荷の低減率は $37 \%$, 冷房負荷比は逆に $5 \%$ 程度増加し, 冷暖房 負荷としての低減率は $22 \%$ となる。断熱・気密性能を向上させた時 の暖房負荷抑制効果は, 全熱交換器を設置した時の暖房負荷抑制効 果より大きい。断熱・気密性能が高い住宅で泠房負荷を減らすには, 通風利用や日射遮蔽性能の向上が必要である。

\section{9. まとめ}

本論文では，寒冷地では暖房負荷の抑制効果が，温暖地ではコー ルドドラフトなどの温熱環境の改善が期待されている全熱交換器を, 冷暖房の設定温度や通風の条件などについて特定の条件を想定し， 温暖地（東京）の戸建住宅に採用した場合の導入効果と利用法つい て検討した注7)。

都市部を想定し, 立地条件などから清掃以外は空開け換気（通風） を行わない「設備依存型」を計算モデルとして, 以下の知見を得た。

・冷暖房負荷抑制効果とコールドドラフトの緩和

1）室内外温度差の大きい 12 月及び 1 ～月の冬期には $10 \%$ 程度暖 房負荷が低減する。

2）外気温の低い冬期に給気によるコールドドラフトが緩和され, 温熱環境が改善されるが，夏期には給気温度が外気温度を上回る 場合もある。

3）夏期である $7 \cdot 8$ 月は，2 3\%程度の冷房負荷の低減となる。 
4）中間期の 5〜6 月及び 9 10 月には負荷比が 100\%を超え，全熱 交換器が逆効果となる場合がある。中間期の泠房日には, 夏期の 夕刻や朝方と同様, 内部発熱や日射による受熱, 室間の影響など, 建物全体システムの挙動で，還気エンタルピーが外気エンタルピ 一を上回り，熱回収が逆効果になっているためである。

5）したがって，夏期の夜間（就寝時に冷房するケースを除く）や 中間期には，熱交換をしないような工夫が必要である。

6）全熱交換換気ユニット内部において，排気系空気が給気系空気 に混入してしまう本研究で想定した全熱交換換気ユニットでは, 中間期の還気エンタルピーが外気エンタルピーを上回る冷房日に おいて，予想される空気質の悪化に加えて冷房負荷も増加する。

7）運転時間が長く, 室温が安定している時に, 全熱交換器は冷暖 房負荷の抑制効果が高い。

- 建物の断熱・気密性能向上時の冷暖房負荷抑制効果に関して

1）外皮からの熱損失が小さくなり，換気による熱損失の割合が増 加し, 全熱交換器の暖房負荷の抑制効果が大きくなる。

2）高断熱・高気密化により，全熱交換器の暖房負荷の抑制効果は 大きくなるが，内部発熱・日射受熱等により冷房負荷は増加する 傾向にある。

また，冷暖房に標準的と思われる通風を加え，就寝時の暖房を取

り止めた「一般型」を計算モデルとして, 以下の知見を得た。

1）冷房負荷の年積算值は統計や実態調查と大きな開きがあり，冷 房の設定温度・発停条件や通風条件が冷房の使用実態と異なって いると考えられるが，通風による冷房負荷の低減率は $22 \%$ あり 実態調查の冷房負荷低減率の $30 \%$ 弱に近いものとなった。

2) 就寝時の暖房 $\left(18^{\circ} \mathrm{C}\right)$ の取り止めにより，20\%程度暖房負荷が 低減される。

温暖地域で全熱交換器の導入効果を高めるためには, 断熱・気密・ 日射遮蔽などの建築的省エネルギー手法を採った上で, 利用法に関 しては，夏期の冷涼な夜間（就㝊時に冷房するケースを除く）や中 間期に熱交換をしないような工夫が必要であり, 状況に応じて通風 をとることが望ましい。

全熱交換換気ユニットを採用することにより様々な効果が期待で きるが，換気動力は増加する傾向にある。第 1 種換気方式は, 確実 な給気・排気が期待でき，空気質の観点からは望ましいが，給気・ 排気の両方に機械力を用いるため, 電力消費量が問題となる。集合 住宅では，水周りに開口部がないことも多く，換気動力の抑制や水 周り排気の重要性を考えると, 室内空気質に加えて, 省エネルギー や温熱環境の観点から, 第 3 種換気方式との総合的な性能評価比較 が必要だといえる。

\section{謝 辞}

本研究の一部は，国土交通省総合技術開発プロジェクト「循環型 社会及び安全な環境の形成のための建築・都市基盤整備技術の開発」 及び独立行政法人建築研究所研究課題「エネルギーと資源の自立循 環型住宅に係わる普及支援システムの開発」の一環として実施した。 ここに記して委員各位に感謝の意を表します。また，モデルの作成 に際しご協力を頂いた長井達夫准教授 (東京理科大学), 大西由哲氏 （清水建設技術研究所）に厚く御礼申し上げます。
注

注 1) 本研究では，全熱交換換気ユニットの圧力バランスと有効換気量率に関 する既往研究 ${ }^{11)}$ の実験結果を基にユニットをモデル化している。風量調整 は給排気口などの端末で調整するのが一般的であるが，実験は換気モード 「強」のみで行っており，この換気モードにおいて端末の圧力調整で風量を 減少させるとユニット内が極度の負圧になり，想定外の使用状況となって 実験結果が反映されない。他に詳細なデータが入手できないことから，送 風機の $\mathrm{PQ}$ 特性を原点に関して相似に縮小した ${ }^{22)}$ 。

注 2) ユニットのケーシングの熱コンダクタンスは，材質が亜鉛鋼板であるこ とから，熱伝導率を $48.05 \mathrm{~W} / \mathrm{m}^{2}$ ，材厚さを $1.5 \mathrm{~mm}$ ，ケーシング面積を $0.162 \mathrm{~m}^{2}$ とし, (総合) 熱伝達率は室内側 $9 \mathrm{~W} / \mathrm{m}^{2} \mathrm{~K}$, チャンバ内側 $23 \mathrm{~W} / \mathrm{m}^{2} \mathrm{~K}$ として算出した。

注 3) ユニットのケーシングの熱コンダクタンスを設定していることから，各 チャンバはユニットを設置した空間温度の影響を受ける。本モデルでは小 屋裏は断熱空間外であり，ユニットを小屋裏に設置した場合は全熱交換器 による冷暖房負荷低減量が小さくなることが考えられる。しかしながら， ユニットや部材は断熱空間内に設置することが一般的であること，メンテ ナンス性を考慮してホール内や納戸にユニットが設置されているケースが

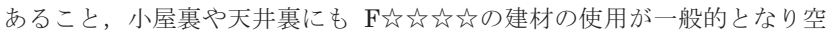
気質が室内に近いことが予測されることなどから，ユニットの設置場所を 1 階ホールに設定している。

注 4) 有効換気量率測定時のバックグランドのトレーサガス濃度を 0 とすると, 質量収支から式(2)が成り立つ。

$C_{O A} Q_{O A}=C_{S A} Q_{S A}$

ここに, $C_{O A}$ : 外気トレーサガス濃度, $C_{S A}$ : 給気トレーサガス濃度, $Q_{O A}$ : 外気経路の風量 $\left[\mathrm{m}^{3} / \mathrm{h}\right], Q_{S A}$ : 給気経路の風量 $\left[\mathrm{m}^{3} / \mathrm{h}\right]$ である。

有効換気量率(NAVR)は, JRA $4056^{23)}$ の有効換気量率測定法の外気基準 法より，

$$
N A V R=\frac{C_{S A}-C_{R A}}{C_{O A}-C_{R A}}
$$

式(2), 式(3)上り, 有効換気量率（給気系の混入率）は式(4)となる。

$$
N A V R=\frac{C_{S A}}{C_{O A}}=\frac{Q_{O A}}{Q_{S A}}
$$

注 5) ダクト系の圧力損失の計算は, 全圧基準で行い, 式(5)により計算した ${ }^{24)}$ 各部材は対象ユニットと同一メーカーのものを採用し，端末・分岐・曲 りの圧力損失係数, ダクトの摩擦係数などはメーカーの技術資料の值を用 いた。

$P_{r}=\zeta_{O} \cdot P_{V O} \cdot\left(Q_{O} / Q_{S O}\right)^{2}+\zeta_{I} \cdot P_{V I} \cdot\left(Q_{I} / Q_{S I}\right)^{2}+\sum\left(\lambda_{i} \cdot L_{i} / D_{i}+\zeta_{B i}\right) \cdot P_{v i} \cdot\left(Q_{i} / Q_{S i}\right)^{2}$

$$
\text { ここに, }
$$

$P_{r}:$ 圧力損失の合計

$[\mathrm{Pa}]$

$\zeta_{O}:$ 外部端末換気口の圧力損失係数

$[-]$

$\zeta_{I}:$ 室内端末換気口の圧力損失係数

$[-]$

$\lambda:$ ダクトの摩擦係数

$[-]$

$D$ : ダクトの直径 $[\mathrm{m}]$

$L:$ ダクトの長さ [m]

$\zeta_{B}$ : 曲り・分岐等の圧力損失係数の検証単位における合計 $[-]$

$P_{V}$ : ダクト径に対応して求める基準動压 $[\mathrm{Pa}]$

$P_{V}=0.5 \cdot \rho \cdot\left(Q_{S} / 3600 / A\right)^{2}$

$\rho$ : 空気密度

$A:$ ダクト断面積

$Q:$ 検証単位の必要風量

$\left[\mathrm{kg} / \mathrm{m}^{3}\right]$

$Q_{S}$ : ダク卜径，端末換気口の接続径に対応する基淮風量 $\left[\mathrm{m}^{3} / \mathrm{h}\right]$

この場合において, 添字 $\mathrm{O}$ は外部端末換気口を, I は室内端末換気口を, i は最長経路のダクトの曲がり及び分岐毎に分割した検証単位を示すもの とする。

注 6) 世带あたりの冷房エネルギー消費量の年積算值は, 2004 年の統計 19)で $1.2 \mathrm{GJ}$ (東京都，戸建・集合の区別なし），2006 年度の実態調査 ${ }^{21}$ )で $1 \mathrm{GJ}$ 程度（III地域に近い気候を除く IV 地域, 戸建住宅, 暑さを感じた時エアコ ンのみ使用するパターンでは $1.5 \mathrm{GJ}$ 程度 ${ }^{20)}$ ) となっており，本シミュレー ションの結果とは大きな開きがあるが，シミュレーションによる住宅の熱 負荷計算結果 12 ), 25) と比較すれば妥当な值である。これは, 冷房エネルギー 消費量は世帯によりばらつきが大きい26)ことや，冷房中の室温は平均で 
$27.6^{\circ} \mathrm{C}$ と高く, 子供室でエアコンを使用する世帯が少ない 17$) こ と, ~ 8$ 割を 超える世帯がエアコンの使用と併せて空開け行動や扇風機等を使用してい る20)ことなどが要因と思われる。

注 7)近年では, 全熱交換器の熱交換効率やエンタルピー交換効率に向上が見 られるため, 本研究の成果がすべての全熱交換換気ユニットの導入効果を 示すものではない。

\section{参考文献}

1) Yoshihiro TORIUMI et al.: ENERGY SAVING EFFECT BY CENTRAL VENTILATION WITH TOTAL HEAT RECOVERY INSTALLED IN A DETACHED HOUSE, Indoor Air Quality, Ventilation and Energy Conservation in Buildings (IAQVEC 2007) PROCEEDINGS II, pp.546-553, October 2007

2）(財)日本エネルギー経済研究所 計量分析ユニット： $\mathrm{EDMC} /$ エネルギ 一・経済統計要覧（2006 年度版），(財)省エネルギーセンター, pp.91

3）日本工業標準調査会：全熱交換器 JIS B 8628, 日本規格協会, 2003.3

4) 中村公亮ほか: 蒸暑地における断熱気密住宅の温熱環境亡空気環境に関 する研究（その 10）全熱交換器の熱交換状況についての実測結果, 日本 建築学会大会学術講演梗概集，D-2, pp.971-972, 1999.9

5）持田 灯ほか:バルコニー一体型ソーラー利用集合住宅換気空調システ ムに関する研究（その 1) 全体システム概要とその省エネルギー性能の試 算，日本建築学会大会学術講演梗概集，D-2，pp.583-584, 2003.9

6）義江龍一郎ほか:バルコニー一体型ソーラー利用集合住宅換気空調シス テムに関する研究 (その 4) 換気装置の自動制御運転実績, 日本建築学会 大会学術講演梗概集, D-2, pp.641-642, 2004.8

7）佐竹 晃ほか:バルコニー一体型ソーラー利用集合住宅換気空調システ ムに関する研究（その 6) 夏期のシステム運転特性と室内環境実測結果, 日本建築学会大会学術講演梗概集，D-2, pp.1309-1310, 2005.9

8）奥山博康: 建築物の熱回路網モデルに関する理論的研究, 学位論文, 早 稲田大学, 1987.12

9）次世代省エネルギー基準解説書編集委員会: 住宅の省エネルギー基準の 解説，(財)建築環境・省エネルギー機構, 2002

10）井上宇一：空気調和ハンドブック，改訂 4 版，丸善, pp.281-289, 1996

11）倉渕 隆・鳥海吉弘ほか：住宅用全熱交換換気ユニットの有効換気量率 測定法に関する研究 第 2 報一各種ユニットへの測定法の適用と換気回 路網モデル，空気調和・衛生工学会論文集，No.121，pp.1-7，2007.4

12）日本建築学会 : 拡張アメダス気象データ, 丸善, 2000

13）西澤繁毅ほか: 住宅の密集度が風圧係数および通風量に及ぼす影響, 空
気調和・衛生工学会大会学術講演論文集, pp.1889-1892, 2007.9

14）小峯裕己：住宅ビルダーのための常時換気設備の選定マニュアル，トス テム建材産業振興財団, pp.58-69, 2007.7

15）澤地孝男ほか: 省エネルギー効果検証を目的とした生活模擬手法を含む 実験手法の提案 住宅のための省エネルギー手法の実験的研究に関する 研究 その 1, 日本建築学会環境系論文集, No.621, pp.69-76, 2007.11

16）鳥海吉弘: 戸建住宅における機械換気システムの性能評価に関する研究, 学位論文, 東京理科大学, pp.96-103, 2007.12

17）草刈和利・井上 隆ほか: アンケートによる一般家庭での冷房使用実態 調査（第 1 報）居間・主寝室・子供室の冷房使用実態，空気調和・衛生工 学会大会学術講演論文集, pp.1435-1438, 2007.9

18）倉㴊 隆・鳥海吉弘ほか：地域性・建物気密性能を考慮した各種換気シ ステムの性能評価に関する研究 第 1 報一第IV地域 (東京) 戸建住宅を対 象とした各種換気システムの比較検討, 空気調和・衛生工学会論文集, No.117, pp.1〜10, 2006.12

19）住環境計画研究所：家庭用エネルギー統計年報 2004 年版, pp.221, 2006.1

20）酒井涼子・井上 隆ほか：アンケートによる一般家庭での冷房使用実態 調査（第 2 報）居間の冷房使用実態と冷房エネルギー消費量の分析, 空気 調和・衛生工学会大会学術講演論文集，pp.1439-1442, 2007.9

21）森原佑介・井上 隆ほか：アンケートによる一般家庭での冷房使用実態 調査（第 3 報）住宅内エネルギー消費の実態と居住者の認識，空気調和・ 衛生工学会大会学術講演論文集, pp.1443-1446, 2007.9

22）奥山博康・大西由哲：送風機の設計風量と全圧から P-Q 特性曲線を生 成する方法, 空気調和・衛生工学会大会学術講演論文集, pp.1089-1092, 2006.9

23）日本冷凍空調工業会：全熱交換器 有効換気量試験方法 JRA 4056, 2003.11

24）(財)ベターリビング : 建築基準法に基づく換気設備の型式認定申請ガイ ド, pp.7-10, 2003.12

25）奥山博康：換気回路網モデル計算プログラム NETS の検証, IBPSAJapan 講演論文集，pp.15-22，2002.6

26）水谷 傑・井上 隆ほか: 住宅内における用途別エネルギー消費と住ま い方の実態に関する研究 -アンケート調査に基づく分析一, 日本建築学 会環境系論文集，No.609，pp.117-124，2006.11

(2008年12月 5 日原稿受理，2009年 4 月30日採用決定） 